\title{
THE PURSUIT OF INTERNATIONAL OPPORTUNITIES IN FAMILY FIRMS: GENERATIONAL DIFFERENCES AND THE ROLE OF KNOWLEDGE-BASED RESOURCES
}

\author{
Hanqing Fang \\ Department of Business and Information Technology \\ Missouri University of Science and Technology \\ 101 Fulton Hall, 301 W. 14th St., Rolla, MO, 65409 \\ Tel.662-617-9499; chevyfhq@gmail.com
}

\section{Josip Kotlar}

Centre for Family Business, Department of Entrepreneurship, Strategy and Innovation

Lancaster University Management School

Bailrigg, Lancaster (UK), LA1 4YX

Tel. +44 (0)1524 594045; j.kotlar@lancaster.ac.uk

\section{Esra Memili}

Assistant Professor; Department of Business Administration

Bryan School of Business and Economics

University of North Carolina at Greensboro

PO Box 2617; Greensboro, NC, 27402-6170

Tel.662-617-1459; e_memili@uncg.edu

\section{James J. Chrisman}

Professor; Department of Management and Information Systems

College of Business

Mississippi State University

Mississippi State, MS 39762

Tel.662-325-1991; jchrisman@ cobilan.msstate.edu and

Centre for Entrepreneurship and Family Enterprise; University of Alberta

\author{
Alfredo De Massis \\ Professor; School of Economics \& Management \\ Free University of Bozen-Bolzano \\ Piazza Università 1, 39100 Bozen/ Bolzano (Italy) \\ Tel. + 3904710 13303, alfredo.demassis@unibz.it \\ and
}

Department of Entrepreneurship, Strategy \& Innovation, Lancaster University Management School

(UK)

\section{Paper accepted for publication in the Global Strategy Journal}

Please cite as:

Fang, H., Kotlar, J., Memili, E., Chrisman, J. J., \& De Massis, A. (2018). The pursuit of international opportunities in family firms: Generational differences and the role of knowledge - based resources. Global Strategy Journal, 8(1), 136-157. 


\section{THE PURSUIT OF INTERNATIONAL OPPORTUNITIES IN FAMILY FIRMS: GENERATIONAL DIFFERENCES AND THE ROLE OF KNOWLEDGE-BASED RESOURCES}

We argue that the willingness (attitude toward risk and socioemotional wealth) and ability (extent of control) of family decision-makers influences the internationalization of family firms and that the relationship is moderated by knowledge-based resources. We then hypothesize how the internationalization of family firms led by founding and later generation family members differs from the internationalization of non-family firms. We also hypothesize how the moderating role of knowledge-based resources influences the internationalization of family firms. A longitudinal analysis of 4,925 firm-year observations of S\&P 1500 manufacturing firms from 2002 to 2008 support our theoretical arguments. Results show that compared to non-family firms, family firms run by founding (later generation) family members internationalize less (more). Knowledge resources increase (decrease) the internationalization of founder-led (later generation) family firms.

\section{INTRODUCTION}

Internationalization represents a critical strategic decision for large firms (Hitt et al., 1994, 1997; Wan \& Hoskisson, 2003). Expanding into foreign markets can potentially provide many benefits, such as economies of scale and scope, market power, and learning from foreign partners and competitors (Geringer et al., 1989; Hitt et al., 1997; Rugman \& Verbeke, 2001). However, internationalization also represents a high risk strategic commitment that may dilute family control and destabilize the achievement of the non-economic goals of family owners. Prior research shows that differences in firm ownership can result in variations in internationalization (e.g., Tihanyi et al., 2003). Moreover, prior family business literature points to important differences in internationalization between family and non-family firms (Gallo \& Garcia Pont, 1996; Gallo \& Sveen, 1991; Pukal; \& Calabrò, 2014). This research stream generally shows a negative relationship 
between family ownership and internationalization (e.g., Fernández \& Nieto, 2005; Gomez-Mejia et al., 2010), suggesting that family firms are often risk averse and reluctant to expand beyond domestic boundaries. ${ }^{1}$ Although internationalization of family firms has received attention (Gallo \& Garcia Pont, 1996; Gallo \& Sveen, 1991; Gomez-Mejia et al., 2010; Pukal; \& Calabrò, 2014; Singla et al., 2014; Zahra, 2003), important gaps in the literature remain.

Previous studies often draw upon either a willingness or, more usually, an ability perspective to explain strategic decision making in family firms, but both perspectives are needed to thoroughly understanding the strategic behavior of family firms (De Massis et al., 2014). The ability perspective suggests that the extent of ownership provides family members with power and discretion to make strategic decisions (e.g., Anderson \& Reeb, 2003; Carney, 2005). However, given equal ability, the willingness of family owners to engage in international activities is based on the extent to which such decisions are consistent with their economic and non-economic goals (Gomez-Mejia et al., 2010), which are likely to differ from those of non-family firms (Chrisman, Chua, Pearson, \& Barnett, 2012). Furthermore, family involvement in business may influence the investments family firms make in knowledge-based resources in comparison to non-family firms (De Massis, Kotlar, Frattini, Chrisman \& Nordqvist, 2016; Habbershon \& Williams, 1999). Depending on their nature, these resources can facilitate or hamper international expansion.

The separation of these perspectives can lead to divergent theoretical predictions and inconsistent empirical findings. Noting that these perspectives are complementary rather than mutually exclusive, we theorize that given similar levels of family ownership - and therefore similar ability - the willingness to internationalize is likely to vary among family firms depending on whether the founding or later generations of the family are in control. Likewise, given similar levels

\footnotetext{
${ }^{1}$ Family firms are defined by a family's involvement in a firm, which allows it to pursue family-centered goals as well as utilize family-based resources in its strategic initiatives (Bennedsen, Perez-Gonzalez and Wolfenzon, 2010; Chua, Chrisman and Sharma, 1999).
} 
of willingness, the ability of family firms to internationalize is likely to vary from each other and from non-family firms according to the level of ownership held by the family. Thus, owing to differences in goals and the discretionary power to act, family firms owned and managed by founding and later generation family members are expected to differ in their level of internationalization. Furthermore, family firms are also expected to differ from each other and from non-family firms in their capacity to utilize knowledge-based resources, which should have interactive effects on internationalization.

Our paper contributes to the literature by combining the willingness and ability perspective with the knowledge-based resource perspective to argue that the proclivities of different types of family firms to engage in international markets vary and that these proclivities are moderated by the availability of critical resources for internationalization. With the exception of a few studies, such as Memili et al. (2015), past research often does not take into account the heterogeneity that exists between family firms run by founding and later generations of a family. Although the family business literature has largely recognized that family firms owned and managed by founders tend to have better performance than either family firms owned and managed by later generations of the family or non-family firms (e.g. Le Breton-Miller \& Miller, 2013; Miller et al., 2007), inquiries regarding how these differences occur are limited. Thus, we further contribute to the literature by showing one reason why founder-led family firms differ from other family firms.

The purpose of this paper is to examine how variations in the extent of control (a determinant of ability) combined with differences in the goals of founding and later generation family ownermanagers (a determinant of willingness) influences their engagement in international activities and how the availability of knowledge-based resources moderates these relationships. Our longitudinal analysis of Standard \& Poor's (S\&P) 1500 manufacturing firms shows that in comparison to nonfamily firms, as the ownership of family firms managed by the founding generation of a family goes up, internationalization goes down, whereas the amount of family ownership of firms managed by 
later generation family members has the opposite effect. Moreover, we show that the availability of knowledge-based resources moderates the relationship between founding and later generation family ownership and internationalization. We find that the level of knowledge-based resources and founding (later) generation ownership positively (negatively) influence internationalization. Overall, our results provide support for both the ability and willingness perspective (De Massis et al., 2014) and the knowledge-based view as it applies to family firms (Barney, 1991; Grant et al., 1992; Habbershon \& Williams, 1999; Nahaphiet \& Ghoshal, 1998). Hence, our paper contributes to the family business, knowledge-based view, and internationalization literatures.

In the reminder of the paper, we review the literature on the influence of family involvement and knowledge-based resources on internationalization. We then develop hypotheses, describe our methods and results, and finally, discuss the implications and limitations of the study.

\section{THEORETICAL BACKGROUND}

The willingness and ability perspective of De Massis et al. (2014) is based on the premises, derived from the behavioral theory of the firm, that (a) different coalitions of owners tend to have divergent interests and goals, (b) the salience of owners' goals in strategic decision-making is dependent upon their power (control rights) to negotiate on behalf of their interests, and (c) owners have multiple goals, that can be either economic or non-economic (Cyert \& March, 1963). Thus, the willingness and ability perspective predicts that international strategy is primarily driven by the extent to which firm owners (1) believe that their economic and non-economic utilities can be better achieved by implementing such a strategy, and (2) have the authority to make decisions concerning the execution of the firm's strategy.

The willingness and ability perspective indicates that the authority and desire of owners to act is critical, but new strategic actions also require that the firm has the capacity to act. Put differently, organizational resources are believed to shape strategic decisions and this is true for family (De Massis, Di Minin \& Frattini, 2015; Habbershon \& Williams, 1999) as well as non-family firms 
(Barney, 1986, 1991). Thus, this perspective focuses on firm resources as drivers of strategic behavior (Hitt \& Ireland, 1985), particularly those accruing from family involvement (Habbershon \& Williams, 1999). Resources must also be integrated and deployed effectively in order to achieve superior performance (Sirmon \& Hitt, 2003; Sirmon et al., 2008). Firms need to develop advanced yet flexible control and evaluation systems to ensure that complex, knowledge-based resources can be added, shed, and bundled as required. Indeed, as Hansen, Perry, and Reese conclude, "what a firm does with its resources is at least as important as which resources it possesses.” (2004: 1280).

While we recognize the fundamental distinctions between these two tracks, we also believe they deal with complementary factors that influence decision-making in organizations. Put differently, we argue that family control (ability), goals (willingness), and resources all affect family firm decision-making. Here, "willingness" is defined as the inclination of family owners to use strategies, which may be idiosyncratic in nature, to achieve family-centered (economic and noneconomic) goals. In turn, "ability" is defined by the extent of family ownership which provides the family with the power and discretion to control firm decision-making. Thus "ability" is necessary to translate family-centered goals into firm behaviors and to apply resources to obtain the desired ends from those behaviors. Theoretically, this means that the effect of firm resources on strategic behaviors in family firms is contingent upon the extent of family ownership in business. In this study, we focus on whether ownership is held by the founding generation or a later generation of the family, as these disparate family owners tend to have heterogeneous goals (Chrisman \& Patel, 2012; GomezMejia et al., 2011; Miller et al., 2007) and resources (Sirmon \& Hitt, 2003) that lead to differences among those firms as well as in comparison to non-family firms.

\section{Family Ownership and Internationalization}

As noted above, the willingness and ability perspective in family business research suggests that the drivers of decision-making in family business are, respectively, (1) the economic and noneconomic goals of family owners (Berrone et al., 2012; Chrisman et al., 2012; Chrisman \& Patel, 
2012) and (2) the power and discretion conferred by the extent of ownership the family holds (Carney, 2005). In terms of international strategy, family owners have an economic incentive to diversify the firm in order to reduce overall variance in expected returns (Alessandri \& Seth, 2014; Chen et al., 2014; Goranova et al., 2007; Pukal; \& Calabrò, 2014; Zahra, 2003) and/or conform to industry norms (Miller et al., 2013). Accordingly, family owners should have economic incentives to internationalize in order to reduce their dependence on a single source of revenues in the domestic market and/or justify the family's control to external constituencies by conforming to the actions of competitors. Although compelling, Gomez-Mejia et al. (2010) argue that family owners' choices about internationalization are more likely to reflect their concerns for attaining family-centered noneconomic goals or preserving socioemotional wealth. Socioemotional wealth (SEW) encompasses the non-economic benefits that family owners can obtain through the control of the firm, including the ability to exercise authority and influence, the emotional value of owning a firm, family members' identification with the firm, and renewal of family bonds to the firm through dynastic succession (for a review, see Berrone et al., 2012). According to Gomez-Mejia et al. (2010), internationalization leads to the dilution of such benefits. Hence, internationalization poses a dilemma for family firms that is not faced in non-family firms, as such decisions may require a tradeoff between economic benefits associated with risk reduction and non-economic benefits associated with preserving socioemotional wealth. ${ }^{2}$

Consistent with the notion of family owners' need to diversify their economic risk or conform to prevailing norms, some studies have shown that family ownership will increase internationalization (Alessandri \& Seth, 2014; Chen et al., 2014; Goranova et al., 2007; Pukal; \& Calabrò, 2014; Zahra, 2003). Conversely, other research has demonstrated that family ownership is negatively related to internationalization, confirming family owners' desire to preserve SEW

\footnotetext{
2 The terms non-economic goals and socioemotional wealth are used interchangeably in this study since achievement of the former creates the latter and the latter influences the former (Berrone et al., 2012; Chrisman et al., 2012; Chrisman, Memili, \& Misra, 2014).
} 
(Arregle et al., 2012; Gomez-Mejia et al., 2010). We argue that these conflicting results might be reconciled through an analysis of the differences between founding and later generation family firms. In particular, we believe that, even if founding and later generation family firms are characterized by similar ability to influence firm behavior, founding generation family firms would be more willing to preserve socioemotional wealth than later generation family firms. Since the importance of SEW tends to diminish in later generations (Gomez-Mejia et al., 2011), economic goals associated with reducing business risk and/or conforming to industry norms should hold greater sway when control is held by later generations of family owners (Gomez-Mejia et al., 2007). Thus, examining the differences in internationalization of founding and later generation family firms holds much promise to enhance current understanding of heterogeneity of family firms.

\section{Differences between Founding and Later Generation Family Owners}

The family business literature has long emphasized that in addition to a distinction between family and non-family firms, there is a fundamental distinction between firms run by founding and later generation family owners (e.g., Morck \& Yeung, 2003; Pérez-González, 2006). Research shows that family attachment to the firm is highest when the firm is owned and managed by members of the founding generation of the family, whereas it tends to weaken as the business is passed onto subsequent generations (Chua et al., 1999; Gómez-Mejía et al., 2007; Le Breton-Miller \& Miller, 2013). Founding family owners who have invested their time, energy, and funds in the firm since its inception are characterized by a strong personal attachment, commitment, and identification with the firm, and are thus likely to place high emphasis on protecting their socioemotional endowments that can be passed on to members of their immediate family by favoring strategies consistent with their non-economic goals (Gómez-Mejía et al., 2007). In this regard, internationalization may not appear as an appealing strategy for founding family owner-managers compared to owner-managers from later generation family firms or firms that are not owned or managed by family members. 
Internationalization often relies upon external funding through the issuance of new stocks or debt. In either case, obtaining external funds allows parties from outside the family to exert influence and control over the strategic direction of the firm, and thus erodes the authority of the owning family (Gomez-Mejia et al., 2010). Also, internationalization may require sending trusted administrators to foreign countries for the purpose of managing foreign operations. In family firms, these administrators are likely, to the extent possible, to be family members. However, the pool of family managers is limited by the size of the family, which is likely to be particularly constrained in the founding generation. Furthermore, internationalization can engender higher administrative complexity. As family firms may lack family members qualified and willing to manage international activities, international initiatives often require that professional managers with international expertise be brought in from outside the firm, which can corrode the family's authority and identification with the firm (Cruz et al., 2010). Hence, in comparison to family firms owned and managed by later generations or non-family firms, internationalization is likely to encounter greater resistance in family firms run by founding family owners who are primarily interested in preserving SEW (Gomez-Mejia et al., 2010). This is expected to lead to less internationalization. Recalling that ownership and ability are positively correlated, we propose:

Hypothesis 1. There will be a negative relationship between the extent of firm ownership held by founding generation family members and internationalization.

Later generation family owner-managers, however, are not expected to place as much emphasis on SEW considerations since family influence is thought to diminish as ownership passes out of the hands of the founding generation (Gomez-Mejia et al., 2007). The emergence of family branches weakens family ties and identification with the firm (Le Breton-Miller \& Miller, 2013). When ownership is held by later generations of an extended family system (i.e., in sibling partnerships or cousin consortiums), blood ties among family members tend to be diluted and the number of family members dependent upon the firm tends to increase (Kotlar \& De Massis, 2013). As such, the salience of economic goals is likely to rise, reducing the aversion to the loss of control 
associated with external funding and professional management. Thus, internationalization should be more attractive to later generation family owners than founding family owners.

In addition, later generation family firms are often exposed to higher pressure for strategic conformity (Miller, Le Breton-Miller, \& Lester, 2013). Strategic conformity refers to firm behaviors that follow prevailing routines and strategies in the market. Later generation family owners and managers are likely to be scrutinized more closely by the public because of a fear that their positions have been secured through nepotism rather than competence (Bertrand \& Schoar, 2006, Morck et al., 2005). Therefore, later generation family members are likely to consider strategic conformity as necessary to gain legitimacy by signaling to outsiders that they can run the firm as effectively as founders or non-family managers. As a result, when ownership is held by later generations of the family, the family firm is more likely than firms owned by the founding generation to internationalize to convince non-family stakeholders that it is capable of achieving acceptable, if not, superior performance.

Indeed, owing to an enhanced need to prove their competence to outsiders and because they have greater discretion to act, family firms owned by later generations are expected to respond to pressures to reduce risk, and improve returns through strategic conformity by engaging in strategies such as internationalization even more aggressively than non-family firms. Thus, we propose:

Hypothesis 2. There will be a positive relationship between the extent of firm ownership held by later generation family members and internationalization.

\section{Knowledge-Based Resources and Internationalization}

As discussed above, the ability perspective assumes that discretion and control determine a firm's strategic choices. However, according to the Knowledge-Based View (KBV), organizational knowledge is the most important resource, and strategic decisions - such as internationalization - are influenced by both the availability and composition of knowledge within the firm's boundaries (Kogut \& Zander, 1992). Organizational knowledge is different from and more complex than tangible resources because it is a socially constructed, intangible resource. According to Leonard and 
Sensiper (1998), organizational knowledge is more than the sum of individual members' knowledge. Rather, it is a collective resource at the organizational level that stems from the exchange and integration of the knowledge of many individuals (Nahaphiet \& Ghoshal, 1998).

One purpose of this study is to examine how knowledge-based resources created through $R \& D$ activities moderate the effect of founding and later generation family ownership on internationalization. Knowledge-based resources in general are expected to facilitate internationalization for the following reasons. First, knowledge-based resources created through participation in domestic markets can have positive externalities on foreign markets activities. Given the globalization of world economies, it is likely that at least some foreign customers share the same tastes and needs as domestic customers. In this regard, products resulting from domestic knowledgebased activities may also be popular in foreign markets (Kumar, 2009), which may facilitate international activities in foreign domains. Second, aside from the products and brands, the knowledge gained through their development may also be used beyond domestic boundaries. Third, domestic R\&D activities may help a firm develop processes, routines, and practices that can be used in international contexts (Galan \& Sanchez-Bueno, 2009; Hitt et al., 1994; Macher \& Boerner, 2012). The development of routines that can be applied to new situations reduces the need to continually creating new routines (Nadolska and Barkema, 2013), which facilitates entry into foreign markets (Nadolska \& Barkema, 2007).

However, the relationship between knowledge-based resources and internationalization can be complex because firms may vary in terms of their capacity to add, shed, unbundle, and leverage resources (Sirmon \& Hitt, 2003; Sirmon et al., 2007). In this regard, value creation requires firms to coordinate and integrate knowledge (Amit \& Zott, 2001; Eisenhardt \& Martin, 2000; Sirmon et al., 2007; Teece et al., 1997). Nahapiet and Ghoshal (1998) further suggest that the social connections of individuals within the firm is positively related to value creation (Smith et al., 2005). Overall then, knowledge-based resources assist firms in disengaging other resources from prior uses and re- 
bundling them for new uses. This means that the firm must be able to re-organize knowledge gained in domestic markets in order to make it applicable to competition in foreign markets.

\section{Interaction Effects of Knowledge-Based Resources and Family Ownership on Internationalization}

Although founding generation family owners may be reluctant to diversify internationally, when they decide to do so their close monitoring and control, binding ties, emotional attachment, and identification with the firm, may provide them with an advantage in coordinating and integrating available knowledge-based resources compared to either non-family firms or later generation family firms. We argue that these advantages can facilitate internationalization for firms managed by owners from the founding generation.

In founding generation family businesses, family members tend to identify with the firm and perceive it as an extension of the family (Berrone et al., 2012; Steier \& Miller, 2010). This often motivates family members to place a higher priority on common goals than on their self-serving interests (Corbetta \& Salvato, 2004). A focus on common goals mitigates relational conflict among family members (Eddleston \& Kellermanns, 2007) and enhances the communication, sharing, and integration of knowledge, leading to greater value creation (Chirico \& Salvato, 2008; 2014).

Moreover, to the extent that the founding generation acts with future generations in mind, their motivation to create value by exploring alternative uses of knowledge-based resources should be greater. Because family bonds are generally stronger in a single family than an extended family, this long-term orientation is more common in founder-generation family firms than non-family firms or later generation family firms. Hence, compared to later generation family owners, firms run by the founding generation are more likely to pursue strategic initiatives such as internationalization as knowledge-based resources increase. Thus, although less willing to internationalize in general, firms run by the founder generation should be more willing to utilize knowledge-based resources for that purpose as the level of those resources increases. In addition, shared experiences through working together in the entrepreneurial and adolescence stages of the firm help build high levels of 
cohesiveness and emotional attachment among family members that contribute to their capacity to utilize knowledge-based resources (Chirico \& Salvato, 2014; Gersick et al., 1997).

In contrast, the above advantages contributing to the coordination and integration of knowledge in family firms, are likely to diminish in later generations. As family influence and control are diluted through ownership dispersion among family members (Gomez-Mejia et al., 2007), coordination becomes more difficult (Berrone et al., 2012). This coordination problem is different from that found in non-family firms where ownership dispersion is more extensive and individual owners cede control to top management and the board of directors. Relational conflict is also more likely to arise in second or later generations (Eddleston et al., 2008; Gersick et al., 1997), leading to weakening of emotional attachments, identification with the firm, family bonds, and social ties. Such conflicts can interfere with the coordination and integration of knowledge-based resources. Moreover, later generation family members may be less concerned with transgenerational continuity, which is likely to promote more short-sighted and exploitative use of knowledge-based resources. Whereas the founding generation's legitimate power can help direct the focus toward firm performance, descendants may be preoccupied with power struggles amongst themselves, shifting the focus from strategy to politics, which can harm the application of knowledge-based resources to international initiatives. This "race to the bottom" (Bertrand, Johnson, Samphantharak, \& Schoar, 2008) may lead to the use of knowledge-based resources for the private benefit of different coalitions of family owners. Principal-principal agency conflicts can thus be exacerbated as knowledge resources increase and the range of strategic options available to recalcitrant and self-serving family owners become larger.

Even though the concern for the socioemotional wealth of the family as a whole may decrease in later generation family firms, the preferences among different branches of the family or between those involved in the firm as opposed to those who are simply owners may result in higher goal diversity (Kammerlander \& Ganter, 2014; Kotlar \& De Massis, 2013) leading some family 
members to pursue self-centered individual interests rather than common goals and strategies (Gomez-Mejia et al., 2007). Again, this can have a deleterious impact because different coalitions of family owners can wield considerable power. When the coalitions are also represented within the firm, internationalization can retard firm-wide coordination and integration of knowledge-based resources (Chirico \& Salvato, 2014). Importantly, goal and relational conflict are likely to make agreements on whether and how the knowledge gained through R\&D investments can or should be used for international activities more difficult, making the relationship between the two negative rather than positive in later generation family firms.

As a result, we expect that even though on average later generation family firms are expected to internationalize more, higher levels of knowledge-based resources can actually lead to decreasing levels of internationalization owing to the rise of relational and goal conflict and diminished concerns for transgenerational succession (Memili et al., 2015). Thus, we expect the levels of internationalizations in firms owned by later generations of a family compared to those in non-family firms or family firms with founding generation owners to decrease as knowledge resources increase. Hence:

Hypothesis 3. There is an interactive effect of family ownership and knowledge-based resources on the internationalization of founding and later generation family firms, such that:

H3a. Higher levels of both founding generation family ownership and knowledgebased resources have a positive impact on internationalization; and

H3b. Higher levels of both later generation family ownership and knowledge-based resources have a negative impact on internationalization.

\section{METHODS}

Consistent with prior studies investigating publicly traded family firms, the sample includes both family and non-family manufacturing firms listed in the S\&P 1500 from 2002 to 2008 that have at least five years of continuous information available. To ensure homogeneity in the sample, we exclude utility and service firms owing to differences in government regulations and the feasible 
international actions of these firms compared to manufacturing firms. In addition, large publiclytraded firms often generate substantial revenues from international activities. Such firms also invest extensively in knowledge-based resources and utilize those resources to facilitate international initiatives. In this case, the "spillover" effect of knowledge-based resources should be salient. The 2002-2008 period is intentionally chosen as firms' international strategies and knowledge-based resources should vary over such a dynamic period that includes both growth and recession. The S\&P 1500 includes non-family as well as founding and later generation family firms (Miller et al., 2007), and has been previously used in the family business literature (e.g., Chrisman \& Patel, 2012).

The data are longitudinal in nature. To identify founding families and their role in a firm, we examined Hoover's, ExecuComp, Fundinguniverse.com, ancestry.com, firm websites, and company proxy statements. Measures related to corporate governance and family business such as family ownership and family management are obtained from annual firm proxy reports. Other variables, including internationalization, come from the Compustat and Hoover's databases. To ensure the direction of causality, one-year lags between the dependent variable and other variables are used, meaning that the independent variables, moderator and control variables are measured from 2002 to 2007, whereas the dependent variable is measured from 2003 to 2008.

Missing data reduce the sample size to 4,925, which is unbalanced in nature and includes 758 firms across 7 yearly periods. The sample includes 421 (8.6\%) founding generation family business observations, $827(16.8 \%)$ later-generation family business observations and $419(8.5 \%)$ lonefounder-controlled business observations. These proportions are comparable to similar studies exploring publicly-traded firms in the United States (e.g. Miller et al., 2007).

\section{Dependent Variable}

Internationalization is measured as the ratio of foreign sales to total sales, adjusted by industrymedians to mitigate industry-specific effects (Pukall \& Calabrò, 2013). By law, companies that are 
publicly-traded in North America are required to report the extent of revenues originating from foreign countries. On average, about $35.4 \%$ of the total sales come from foreign countries.

\section{Independent Variables}

Consistent with our definition of family firms, we use family ownership to measure our independent variables. We measure family ownership as the percentage of equity ownership held by family members if 1) the family has at least $5 \%$ ownership, and 2) there are at least two family members who are or have been involved as significant owners, top managers, or directors in the firm's history (Miller et al., 2007). Such a measure either signals the presence of a desire for intrafamily succession intention or indicates that intra-family succession intention has occurred in the past (Chrisman \& Patel, 2012). In addition, this measure differentiates family firms from lonefounder firms, which, by definition, do not have multiple family members involved in the business, and from firms controlled by non-family blockholders in which the significant owners are neither family members nor founders (Cannella, Jones, \& Withers, 2015).

We build our independent variables by combining family ownership with information about who is in control of the firm. In particular, we differentiate between founding and later generation family ownership by specifying whether there are second or later generation family members involved in business as significant owners, top managers, or directors. Founding generation family ownership is measured by the extent of family ownership when there is no family member beyond the founding generation, while later generation family ownership is measured by the extent of family ownership when there is involvement by second or later generation family members in the firm. Such a classification has been used previously in the family business literature (Miller et al., 2007). Nonfamily firms are all coded as zero for these two measures.

\section{Interaction Variable}

Following Chatterjee and Wernerfelt (1991), we used the ratio of R\&D expenses to sales to measure knowledge-based resources. We use this variable along with the family generational 
ownership measures to investigate their interactive effects on internationalization. This variable has been widely used in the family business literature (Chen \& Hsu, 2009) and is continuous. The measure reflects that investments in $R \& D$ increase the knowledge of the firm. By using a lagged measure of R\&D we capture previous investments in knowledge-based resources that would be available to support a firm's internationalization.

\section{Controls}

Several control variables are included in the analysis to account for alternative explanations: Family management, TMT size, CEO duality, lone-founder ownership, non-family blockholder ownership, firm size, firm age, firm risk, past performance, debt ratio, advertisement ratio, plant and equipment newness, inventory ratio, and previous international sales. These controls are related to corporate governance, firm attributes and firm's strategic actions. Again, all are measured one year prior to the dependent variable (time t-1).

Family management is measured by the number of family members serving in the top management team (TMT). TMT size is measured by the number of top managers in the TMT. CEO duality is a binary variable (0/1) in which 1 denotes the situation where the CEO also serves as the chair of the board of directors and 0 otherwise. Lone-founder ownership is measured as a percentage of voting shares outstanding held by a founder where no other family members are involved in the firm (Miller et al., 2007). Non-family blockholder ownership is measured by the percentage of ownership controlled by non-family and non-founder insiders. We used logged annual sales to control for firm size. Firm age is measured by the number of years the firm has been in existence since founding. Firm risk is measured by the standard deviation of stock returns for the previous 3 years. Past firm performance is measured by Tobin's $q$ in time t-1, which is a market based measure of firm performance (Anderson \& Reeb, 2004). All of the variables listed above are continuous. We also control for firm's strategic actions beyond internationalization such as the debt ratio (debt/sales), advertising ratio (advertising/ sales), plant and equipment newness (net P\&E/gross 
$\mathrm{P} \& \mathrm{E}$ ) and inventory ratio (inventories/sales). Previous international sales is measured as the proportion of international sales to total sales in time t-1. Descriptive statistics and correlations are shown in Table 1.

Insert Table 1 about here

\section{Instrumental Variables}

We use three sequential steps to control for the possible endogeneity of family ownership due to unobservable organizational or environmental characteristics that are not captured in the control variables, or reverse causality between independent and dependent variables. First, as noted above, we use longitudinal data and apply a one year lag between the dependent variable and other variables, so that the direction of causality can be ensured. Second, we include previous international sales (t-1), which further mitigates the influence of reverse causality in the analysis (Arrelano \& Bond, 1991). Finally, we use the Heckman's (1979) two-stage procedure (e.g. Gómez-Mejía et al., 2007). To do so, we first run a probit model where a family business variable based on a $5 \%$ family ownership threshold is the endogenous variable, and estimate the inverse Mills ratio. We then estimate the regression of internationalization using the inverse Mills ratio from the probit model as another control.

We use three instrumental variables. The first is family trust-holdings affiliated with the largest owner in the firm in a given year, measured as a binary variable in which " 1 " indicated that the owner holds either family trusts or foundations and "0" that the owner does not. Indeed, family owners often choose to use trusts or foundations to take care of family members. Family trustholdings can signal the owners' vision for how the firm will benefit the family but should not be related to internationalization. This variable is obtained from annual proxy statements.

The second instrument is the fraction of industry sales that comes from family firms (i.e. family firm sales/total industry sales), which is naturally related to the probability that a firm in the industry is a family firm, yet is independent of the second stage dependent variable (internationalization) 
because the latter is industry-adjusted. Similar measures have been used in previous studies in the family business (Amit et al., 2015) and finance literatures (Campa \& Kedia, 2002). Similarly, the third instrument is the fraction of advertisement expenditures made by all family firms in a given industry (i.e. family firm advertising expenditures /total industry advertisement expenditures).

All three instrumental variables are significantly and positively related to family ownership variables. As mentioned above, this study uses the Heckman's two-stage approach to control for endogeneity. Model 1 (Table 2) is the first-stage probit treatment model in which the binary variable of family business is regressed against the instrumental variable, moderator and other controls. The lone-founder variable is not included as a control in this model as it is mutually exclusive from the family business variable. All three instrumental variables are significantly and positively related to the family business variable. Combined, these three instruments are significant (F-statistics=197.80, $\mathrm{p}<0.001)$. The probit model also shows a reasonable level of model fit $\left(\mathrm{McFadden} \mathrm{R}^{2}=0.76\right)$. We conclude that the selection of instrumental variables is appropriate.

\section{RESULTS}

Due to the nature of longitudinal data, OLS regression analysis is unable to control for both periodic and cross-sectional influences. A Hausman test $($ Chi Sq. Statistics $=506.72, \mathrm{p}<0.001)$ suggests that the fixed effect model is more appropriate than the random effect model for this study. Thus, we use fixed-effect panel regression for the analysis. Cross-sectional White estimators are used in controlling for serial correlation and heteroscedasticity. Model 2 (Table 2) reports the regression results.

The inverse Mills Ratio $(B=-0.006, p<0.05)$ is found to be significantly related to the dependent variable, which further demonstrates the appropriateness of our two-stage procedure. Family management $(B=0.064, p<0.10)$, TMT size $(B=-0.023, p<0.05)$, lone-founder ownership $(B=0.028, p<0.05)$, non-family ownership $(B=-0.0001, p<0.01)$, firm size $(B=-0.208, p<0.10)$, firm age $(B=0.037, p<0.05)$, firm risk $(B=-0.002, p<0.001)$, previous performance $(B=-0.030$, 
$\mathrm{p}<0.05)$ and previous international sales $(\mathrm{B}=-0.103, \mathrm{p}<0.10)$ are significantly related to internationalization.

In support of $\mathrm{H} 1$ and $\mathrm{H} 2$, family firm ownership held by the founding generation $(\mathrm{B}=-0.004$, $\mathrm{p}<0.01$ ) has a negative impact on internationalization, while family firm ownership held by later generations has a positive impact on internationalization $(B=0.004, p<0.01)$.

Both $\mathrm{H} 3 \mathrm{a}$ and $\mathrm{H} 3 \mathrm{~b}$ are supported. Knowledge-based resources are positively related to internationalization as the level of ownership by the founder generation of a family increases $(\mathrm{B}=$ 0.057, p-value<0.05), and is negatively related to internationalization as the level of ownership by later generations of a family increases $(B=-0.114$, $\mathrm{p}$-value $<0.05)$. Figure 1 offers a graphical representation of the findings. At relatively low levels of knowledge-based resources, ownership by founding generation family members is associated with lower internationalization whereas ownership by later generation family members is associated with higher levels of internationalization. Nevertheless, as knowledge-based resources increase, firms owned by the founding generation of a family show a greater increase in internationalization than firms owned by later generations. When knowledge-based resources reach a relatively high level, founding family ownership is associated with higher internationalization compared to later generation family firms.

\section{Robustness Tests}

We ran additional tests to investigate the robustness of our results. First, instead of using family ownership, we use binary measures of founding and later generation family business, classified by the $5 \%$ family ownership threshold. Such an approach may overlook the fact that the execution of the owning family's "willingness" is dependent upon the extent of the family's ability (ownership). Nonetheless, the results are qualitatively consistent with the primary analysis. However, although the signs of the coefficients for the founding generation family business variable and its interaction with knowledge-based resources are the same, the coefficients become insignificant. In a second robustness test, we use international asset investments instead of international sales as our 
dependent variable. Since the Compustat database does not include a measure of international asset investments, we collected those data from the Thomson Reuters database. We then replicated the analysis using 377 firm-year observations from the S\&P 500 from 2002 to 2007 . In this case, the regression results are consistent with our primary results in both the signs and significance of our variables, providing further support for our main regression results.

Insert Table 2 and Figure 1 about here

\section{DISCUSSION AND CONCLUSIONS}

The contention of our study is that founding family owners differ from later generation family owners as well as from non-family owners in their goals and the strategies used to achieve those goals. We hypothesize, and find supporting evidence, that these differences have heterogeneous influences on internationalization. As such, we respond to calls for studies on how the adoption of family goals and SEW considerations change across different generations of family ownership (Berrone et al., 2012). At the same time, our results help reconcile some mixed findings in past research (e.g., Arregle et al., 2012; Gomez-Mejia et al., 2010; Sciascia et al., 2012) by offering a more complete view of the influence of family ownership on internationalization. In sum, this study provides a better understanding of how different types of family owners and managers influence internationalization, as well as the heterogeneity of family firms' behavior (Chrisman \& Patel, 2012). In other words, this study shows that considering how much an owning family is able to influence firm behavior does not adequately capture how that influence is exercised (Chrisman et al., 2015) because how the influence of family ownership translates into firm behavior is likely to vary in type as well as degree according to the goals of key family stakeholders, their power to govern the firm in a particularistic way, and the amount of resources available to pursue those goals.

Longitudinal regression analyses based on 758 S\&P 1500 manufacturing firms 4,925 firmyears of data from 2002 to 2008 yields several important and interesting insights. First, we found that 
founding generation family ownership is negatively associated with internationalization, whereas later generation family ownership has the opposite effect. Second, we found that knowledge-based resources moderates these relationships in non-obvious ways. Family firms with founding generation ownership and high levels of knowledge-based resources appear more willing to use those resources to pursue internationalization than family firms owned and managed by later generations.

These findings contribute to the family business and KBV literature in several ways. First, most previous family business studies seem to assume that the willingness of family firms to pursue specific strategic behaviors is invariant and all that matters is their ability to do so. By investigating the internationalization of family firms owned by founders versus family firms owned by later generation family members, we demonstrate that strategic behaviors can vary substantially among different types of family firms, implying that their mix of economic and non-economic goals are also highly variable (e.g., Kammerlander \& Ganter, 2014).

Second, we demonstrate that the use of knowledge-based resources from R\&D investments can influence firms' internationalization and moderate the relationship between those strategies and the amount of family ownership held by different types of family firms.

Third, the standard premise is that SEW reduces a family firm's willingness to assume risk and adopt innovative firm strategies. We make a similar argument when hypothesizing the relationship between founding family ownership and international strategy. Nevertheless, we argue and show that family firms owned and managed by the founding generation with high levels of knowledge-based resources may be better suited and more likely to effectively implement international strategies. Hence, our results point to a paradox concerning founding and later generation family firms: founding generation family firms generally appear to be less willing to internationalize, but more willing as the level of knowledge-based resources increase; conversely, later generation family firms are generally more willing to internationalize, but this willingness declines as knowledge-based resources increase. We argue that in the case of founder-owned firms, 
as the levels of knowledge-based resources increase, their concern for the positioning of the firm they will pass on to future generations rises commensurately, representing a convergence of economic and non-economic goals. On the other hand, we argue that increased levels of knowledgebased resources exacerbate the potential for principal-principal conflicts among relationally-distant later generation owners (i.e., family members are more likely to fight the more there is to fight about). This intriguing set of findings not only sheds light on the heterogeneity of family firms, but offers important opportunities for further exploring the discordant influences of different family owners related to strategic decision-making.

\section{Limitations and Future Research Directions}

Despite the contributions of this study to the family business, knowledge-based view, and internationalization literatures, it is also important to acknowledge its limitations. First, we used a sample of firms listed in the S\&P 1500 (and the S\&P 500 in a robustness test), suggesting that our data may restrict the generalizability of our findings in a global context. It has been noted that the spillover of knowledge and mobility of employees are both determined by contextual conditions (Campbell et al., 2012). Hence, our findings may be contingent upon the external environment. Future research could examine our model across different countries, especially those with varying legal regimes (e.g., common versus civil law).

Second, we test our hypotheses using a sample of publicly traded firms. Although S\&P data are commonly used to explore strategic decision-making in family firms (e.g. Block, 2010), we recognize that the generalizability of our findings may be limited to large firms only. We encourage scholars to examine internationalization in small, medium-size, and privately held family firms.

Third, we measured knowledge-based resources based on prior investments in R\&D. Although such investments can certainly increase knowledge-based resources, other forms of investment in innovation are possible. For example, Patel and Chrisman (2014) measure exploratory versus exploitative innovation as well as patents in their study of the risk abatement R\&D strategies 
of family firms. Knowledge resources and entrepreneurial inclinations can also be represented by other variables such as the background and characteristics of the top management team (cf., PérezGonzález, 2006; Sirmon \& Hitt, 2003). Future studies should consider a broader array of variables to capture the development and use of knowledge resources in family firms.

In addition, the findings may vary by time period. For example, 2007-2008 represented the start of a major recession which may have subsequently altered the preferences and strategies of family firms. Therefore, we welcome future research on different time periods.

Aside from the future research directions suggested in the discussion of findings and limitations, there may be other factors that may affect internationalization in publicly-traded family firms. The imminence of succession (Chua et al., 2003) and the family firm incumbents' attitude toward intra-family succession (De Massis, Sieger, Chua, \& Vismara, 2016) are two. The effects of generational differences on internationalization might also vary in family firms depending upon other variables such as their corporate entrepreneurial orientation (Dess et al., 1999; Dess \& Lumpkin, 2005; Lumpkin et al., 2005).

Furthermore, internationalization in family firms might vary depending upon the top management team, board composition (Anderson \& Reeb, 2004), board independence (Klein, Shapiro, \& Young, 2005), leadership styles (Bass, 1990), social capital (Sirmon \& Hitt, 2003), strategic networks (Arregle et al., 2007), and a host of other factors. Although partially captured through our control variables, these contingencies suggest additional ways in which the willingness, ability and knowledge-based resource perspectives of family firms can be applied.

Finally, internationalization may take many forms (e.g., joint ventures, foreign acquisitions, foreign direct investments, etc.). Future work is needed to determine whether the preferences for different methods of international expansion of family and non-family firms, as well as different types of family firms, vary in a systematic way. 


\section{REFERENCES}

Alessandri, T. M \& Seth, A. 2014. The effects of managerial ownership on international and business diversification: Balancing incentives and risks. Strategic Management Journal, 35(13): 2064-2075.

Alvarez, S. A., \& Barney, J. B. 2004. Organizing rent generation and appropriation: Toward a theory of the entrepreneurial firm. Journal of Business Venturing, 19(5): 621-635.

Amit, R., Ding, Y., Villalonga, B., \& Zhang, H. (2015). The role of institutional development in the prevalence and performance of entrepreneur and family-controlled firms. Journal of Corporate Finance, 31, 284-305.

Amit, R., \& Zott, C. 2001. Value creation in e-business. Strategic Management Journal, 22(6-7): 493-520.

Anderson, R. C., \& Reeb, D. M. 2004. Board composition: Balancing family influence in S\&P 500 firms. Administrative Science Quarterly, 49(2): 209-237.

Arregle, J., Hitt, M. A., Sirmon, D. G., \& Very, P. 2007. The development of organizational social capital: Attributes of family firms. Journal of Management Studies, 44(1): 73-95.

Arregle, J., Naldi, L., Nordqvist, M., \& Hitt, M. A. 2012. Internationalization of FamilyControlled Firms: A Study of the Effects of External Involvement in Governance. Entrepreneurship Theory \& Practice, 36 (6): 1115-1143.

Arellano, M., \& Bond, S. 1991. Some tests of specification for panel data: Monte Carlo evidence and an application to employment equations. The Review of Economic Studies, 58(2): 277297.

Barney, J. 1991. Firm resources and sustained competitive advantage. Journal of Management, 17(1): 99-120.

Barney, J.B. 1986 Strategic factor markets: expectations, luck, and business strategy, Management Science, 32(10): 1231-1241.

Bass, B. M. 1990. From transactional to transformational leadership: Learning to share the vision. Organizational Dynamics, 18(3): 19-31.

Berrone, P., Cruz, C., \& Gomez-Mejia, L.R. 2012. Socioemotional Wealth in Family Firms: Theoretical Dimensions, Assessment Approaches, and Agenda for Future Research. Family Business Review, 25(3): 258-279.

Bertrand, M, \& Schoar, A. 2006. The role of family in family firms. The Journal of Economic Perspectives, 20(2): 73-96.

Bertrand, M, Johnson, S., Samphantharak, K., \& Schoar, A. 2008. Mixing family with business: A study of Thai business groups and the families behind them. Journal of Financial Economics, 88: 466-498. 
Block, J.H. 2010. Family management, family ownership, and downsizing: Evidence from S\&P 500 firms. Family Business Review, 23(2): 109-130.

Block, J. H. 2012. R\&D investments in family and founder firms: An agency perspective. Journal of Business Venturing, 27: 248-265.

Cabrera-Suárez, K., De Saá-Pérez, P., \& García-Almeida, D. 2001. The succession process from a resource-and knowledge-based view of the family firm. Family Business Review, 14(1): 3746.

Campa, J. M., \& Kedia, S. (2002). Explaining the diversification discount. Journal of Finance, 57(4): 1731-1762.

Campbell, B. A., Coff, R., \& Kryscynski, D. 2012. Rethinking sustained competitive advantage from human capital. Academy of Management Review, 37(3): 376-395.

Cannella, A. A., Jones, C. D., \& Withers, M. C. 2015. Family-versus lone-founder-controlled public corporations: Social identity theory and boards of directors. Academy of Management Journal, 58(2): 436-459.

Casillas J. C., Acedo F. J., \& Moreno A. M. 2007. International entrepreneurship in family businesses. Edward Elgar Publishing, Cheltenham.

Chatterjee, S., \& Singh, J. 1999. Are tradeoffs inherent in diversification moves? A simultaneous model for type of diversification and mode of expansion decisions. Management Science, 45 (1): $25-41$.

Chatterjee, S., \& Wernerfelt, B. 1991. The link between resources and type of diversification: theory and evidence. Strategic Management Journal, 12(1): 33-48.

Chen, H. L., \& Hsu, W. T. 2009. Family Ownership, Board Independence, and R\&D Investment. Family Business Review, 22(4): 347-362.

Chen, H. L., Hsu, W. T., \& Chang, C. Y. 2014. Family ownership, institutional ownership, and internationalization of SMEs. Journal of Small Business Management, 52(4): 771-789.

Chirico, F., \& Salvato, C. 2008. Knowledge integration and dynamic organizational adaptation in family firms. Family Business Review, 21(2): 169-181.

Chirico, F., \& Salvato, C. 2016. Knowledge internalization and product development in family firms: When relational and affective factors matter. Entrepreneurship Theory and Practice, 40: 201-229.

Chrisman J.J., Fang H., Kotlar J., De Massis A. 2015. A Note on Family Influence and the Adoption of Discontinuous Technologies in Family Firms. Journal of Product Innovation Management, 32(3): 384-388.

Chrisman, J. J., \& Patel, P. J. 2012. Variations in R\&D Investments of Family and Non-family Firms: Behavioral Agency and Myopic Loss Aversion Perspectives. Academy of Management Journal, 55 (4): 976-997. 
Chrisman, J. J., Chua, J. H., Pearson, A. W., \& Barnett, T. 2012. Family involvement, family influence, and family-centered non-economic goals in small firms. Entrepreneurship Theory and Practice, 36: 267-293.

Chrisman, J. J., Memili, E., \& Misra, K. 2014. Nonfamily managers, family firms, and the winner's curse: The influence of noneconomic goals and bounded rationality. Entrepreneurship Theory and Practice, 38(5): 1103-1127.

Chua, J. H., Chrisman, J. J., \& Sharma, P. 1999. Defining the family business by behavior. Entrepreneurship Theory and Practice, 23(4): 19-39.

Chua, J. H., Chrisman, J. J., \& Sharma, P. 2003. Succession and nonsuccession concerns of family firms and agency relationship with nonfamily managers. Family Business Review, 16(2): 89-108.

Chua, J. H., Chrisman, J. J., Kellermanns, F., \& Wu, Z. 2011. Family involvement and new venture debt financing. Journal of Business Venturing, 26(4), 472-488.

Conner, K. R., \& Prahalad, C. K. 1996. A resource-based theory of the firm: Knowledge versus opportunism. Organization Science, 7(5): 477-501.

Corbetta, G., \& Salvato, C. 2004. Self-serving or self-actualizing? Models of man and agency costs in different types of family firms: A commentary on "Comparing the agency costs of family and non-family firms: Conceptual issues and exploratory evidence." Entrepreneurship Theory and Practice, 28: 355-362.

Cruz, C. C., Gómez-Mejia, L. R., \& Becerra, M. 2010. Perceptions of benevolence and the design of agency contracts: CEO-TMT relationships in family firms. The Academy of Management Journal, 53(1): 69-89.

Davis, P. S., \& Harveston, P. D. 1999, In the founder's shadow: Conflict in the family firm. Family Business Review, 12: 311-323.

De Massis A., Di Minin A., \& Frattini F. 2015. Family-driven innovation: Resolving the paradox in family firms. California Management Review, 58(1): 5-19.

De Massis, A., Kotlar, J., Chua, J.H., \& Chrisman, J.J. 2014. Ability and willingness as sufficiency conditions for family oriented particularistic behavior: Implications for theory and empirical studies. Journal of Small Business Management, 52(2): 344-364.

De Massis, A., Kotlar, J., Frattini, F., Chrisman, J., \& Nordqvist, M. 2016. Family governance at work: Organizing for new product development in family SMEs. Family Business Review, 29(2): 189-213.

De Massis, A., Sieger, P., Chua, J.H., \& Vismara, S. 2016. Incumbents' attitude toward intrafamily succession: An investigation of its antecedents. Family Business Review, 29(3): 278-300.

Dess, G. G., \& Lumpkin, G. T. 2005. The role of entrepreneurial orientation in stimulating effective corporate entrepreneurship. Academy of Management Executive, 19(1): 147-156. 
Dess, G. G., Lumpkin G. T., \& McGee, J. E. 1999. Linking corporate entrepreneurship to strategy, structure, and process: Suggested research directions. Entrepreneurship Theory and Practice, 23(3): 85-102.

Dierickx, I., \& Cool, K. 1989. Asset stock accumulation and sustainability of competitive advantage. Management Science, 35(12): 1504-1511.

Eddleston, K. A., Otondo, R. F., \& Kellermanns, F. W. 2008. Conflict, participative decision making, and generational ownership dispersion: A multilevel analysis. Journal of Small Business Management, 46(3): 456-484.

Eddleston, K., \& Kellermanns, F. W. 2007. Destructive and productive family relationships: A stewardship theory perspective. Journal of Business Venturing, 22(4): 545-565.

Eisenhardt, K. M., \& Martin, J. A. 2000. Dynamic capabilities: what are they? Strategic Management Journal, 21: 1105-1121.

Fernández, Z., \& Nieto, M. J. 2005. Internationalization strategy of small and medium sized family businesses: Some influential factors. Family Business Review, 18 (1): 77-89.

Galan, J.I.\& Sanchez-Bueno, M.J. 2009. Strategy and structure in context: Universalism versus institutional effects. Organization Studies 30(6): 609-627.

Gallo, M. A., \& Garcia Pont, C. 1996. Important factors in family business internationalization. Family Business Review, 9 (1): 45-59.

Gallo, M. A., \& Sveen, J. 1991. Internationalizing the family business: Facilitating and restraining factors. Family Business Review, 4(2), 181-190.

Gedajlovic, E., \& Carney, M. 2010. Markets, hierarchies, and families: Toward a transaction cost theory of the family firm. Entrepreneurship Theory and Practice, 34(6): 1145-1171.

Gersick, K. E., Davis, J. A., Hampton, M. M., \& Lansberg, I. 1997. Generation to generation: Life cycles of the family business. Boston, MA: Harvard Business School Press.

Gómez-Mejía, L. R., Haynes, K. T., Núñez-Nickel, M., Jacobson, K. J. L., \& Moyano-Fuentes, J. 2007. Socioemotional wealth and business risks in family-controlled firms: Evidence from Spanish olive oil mills. Administrative Science Quarterly, 52(1): 106-137.

Gomez-Mejia, L. R., Makri, M., Larraza-Kintana, M. 2010. Diversification decisions in familycontrolled firms. Journal of Management Studies, 47(2): 223-252.

Gomez-Mejia, L.R., Cruz, C., Berrone, P., \& De Castro, J. 2011. The bind that ties: socioemotional wealth preservation in family firms. Academy of Management Annals, 5(1): 653-707. 
Goranova, M., Alessandri, T.M., Brandes, P., \& Dharwadkar, R. 2007. Managerial ownership and corporate diversification: a longitudinal view. Strategic Management Journal, 28(3): 211225.

Graves, C., \& Thomas, J., 2008. Determinants of the internationalization pathways of family firms: An examination of family influence. Family Business Review, 21(2): 151-167.

Habbershon, T.G., \& Williams, M.L. 1999. A resource-based framework for assessing the strategic advantages of family firms. Family Business Review, 12: 1-25.

Habberson, T. G., Williams, M., \& McMillan, I. C. 2003. A unified systems perspective of family firm performance. Journal of Business Venturing, 18(4): 451-465.

Hansen, M. H., Perry, L. T., \& Reese, C. S. 2004. A Bayesian operationalization of the resourcebased view. Strategic Management Journal, 25: 1279-1295.

Hitt, M. A., Hoskisson, R. E., \& Ireland, R. D. 1994. A mid-range theory of the interactive effects of international and product diversification on innovation and performance. Journal of Management, 20(2): 297-326.

Hitt, M. A., Hoskisson, R. E., \& Kim, H. 1997. International asset investments: Effects on innovation and firm performance in product-diversified firms. Academy of management Journal, 40(4): 767-798.

Hitt, M.A. \& Ireland, R.D. 1985. Corporate distinctive competence, strategy, industry and performance. Strategic Management Journal, 6, 273-293.

Kammerlander, N., and Ganter, M. 2014. An attention-based view of family firm adaptation to discontinuous technological change: Exploring the role of family CEOs' noneconomic goals. Journal of Product Innovation Management, 32(3): 361-383.

Kellermanns, F. W., \& Eddleston, K. A. 2007. A family perspective on when conflict benefits family firm performance. Journal of Business Research, 60(10): 1048-1057.

Klein, P., Shapiro, D., \& Young, J. 2005. Corporate governance, family ownership, and firm value: The Canadian evidence. Corporate Governance: An International Review, 13(6): 769-326.

Kogut, B., \& Zander, U. 1992. Knowledge of the firm, combinative capabilities, and the replication of technology. Organization Science, 3(3): 383-397.

Kontinen, T., \& Ojala, A. 2010. The internationalization of family businesses: A review of extant research. Journal of Family Business Strategy, 1(2): 97-107.

Kotlar, J., \& De Massis, A. 2013. Goal Setting in Family Firms: Goal Diversity, Social Interactions, and Collective Commitment to Family-Centered Goals, Entrepreneurship Theory and Practice, 37(6): 1263-1288.

Kumar S. 2009. The relationship between product and international asset investments: the effects of short-run constraints and endogeneity, Strategic Management Journal. 30(1): 99-116. 
Le Breton-Miller, I. and Miller, D. 2013. Socioemotional wealth across the family firm life cycle: A commentary on "Family Business Survival and the Role of Boards". Entrepreneurship Theory and Practice, 37(6), pp.1391-1397.

Lee, K. S., Lim, G. H., \& Lim, W. S. 2003. Family business succession, appropriation risk and choice of successor. Academy of Management Review, 28: 657-666.

Leonard, D., \& Sensiper, S. 1998. The role of tacit knowledge in group innovation. California Management Review, 40(3).

Lepak, D. P., Smith, K. G., \& Taylor, M. S. 2007. Value creation and value capture: A multilevel perspective. Academy of Management Review, 32(1): 180-194.

Lippman, S. A., \& Rumelt, R. P. 1982. Uncertain imitability: An analysis of interfirm differences in efficiency under competition. The Bell Journal of Economics, 13(2): 418-438.

Lumpkin, G. T., Wales, W. J, \& Ensley, M. D. 2005. Assessing the context for corporate entrepreneurship: The role of entrepreneurial orientation. In Praeger perspectives on entrepreneurship, ed. T. Habberson and M. Rice, vol. 3: 1-43.

Macher, J.T.\& Boerner, C. 2012. Technological development at the boundaries of the firm: a knowledge-based examination in drug development. Strategic Management Journal 33(9): 1016-1036.

Makadok, R. 2001. Toward a synthesis of the resource-based and dynamic-capability view of rent creation. Strategic Management Journal, 22, 387-401.

Memili, E., Fang, H. C., \& Welsh, D. H. 2015. Value creation and value appropriation in innovation process in publicly-traded family firms. Management Decision, 53(9), 1921-1952.

Miller, D., Le Breton-Miller, I., \& Lester, R. H. 2013. Family firm governance, strategic conformity, and performance: Institutional vs. strategic perspectives. Organization Science, 24(1): 189-209.

Miller, D., Le Breton-Miller, I., Lester, R. H., \& Cannella, A. A. 2007. Are family firms really superior performers? Journal of Corporate Finance, 13: 829-858.

Morck, R. K., Wolfenzon, D., \& Yeung, B. 2005. Corporate governance, economic entrenchment, and growth. Journal of Economic Literature 43(3) 655-720.

Morck, R., \& Yeung, B. 2003. Agency problems in large family business groups. Entrepreneurship Theory and Practice, 27(4): 367-382.

Nadolska, A.M. \& Barkema, H.G. 2007. Learning to internationalise: the pace and success of foreign acquisitions. Journal of International Business Studies 38(7): 1170-1186.

Nadolska, A.M.\& Barkema, H.G. 2013. Good learners: how top management team affect behavior and performance of acquisitions. Strategic Management Journal. DOI: 10.1002/smj. 2172 . 
Nahapiet, J., \& Ghoshal, S. 1998. Social capital, intellectual capital, and the organizational advantage. Academy of Management Review, 23(2): 242-266.

Patel, P.C., \& Chrisman, J.J. 2014. Risk abatement as a strategy for R\&D investments in family firms. Strategic Management Journal, 35(4): 617-627.

Penrose, E. G. 1959. The theory of the growth of the firm. New York: Wiley.

Pérez-González, F. 2006. Inherited control and firm performance. The American Economic Review, 96(5): 1559-1588.

Polanyi, M. 1962. Personal knowledge: Towards a post-critical philosophy. London, UK: Psychology Press.

Pukall, T. J., \& Calabrò, A. 2014. The internationalization of family firms: A critical review and integrative model. Family Business Review, 27(2), 103-125.

Rugman, A. M. 1979. International asset investments and the multinational enterprise, Lexington Books, Lexington, MA.

Rugman, A. M., \& Verbeke, A. 2001. Subsidiary-specific advantages in multinational enterprises. Strategic Management Journal, 22(3): 237-250.

Rumelt, R. P. 1984. Towards a strategic theory of the firm. In Competitive strategic management, ed. R. B. Lamb, 556-570. Englewood Cliffs, NJ: Prentice Hall.

Sciascia, S., Mazzola, P., Astrachan, J. H., \& Pieper, T. M. 2012. The role of family ownership in international entrepreneurship: Exploring nonlinear effects. Small Business Economics, 38 (1): $15-31$.

Sirmon, D. G., \& Hitt, M. A. 2003. Managing resources: Linking unique resources, management, and wealth creation in family firms. Entrepreneurship Theory and Practice, 27: 339-358.

Sirmon, D. G., Hitt, M. A., \& Ireland, R. D. 2007. Managing firm resources in dynamic environments to create value: Looking inside the black box. Academy of Management Review, 32(1): 273-292.

Smith, K., Collins, C., \& Clark, K. 2005. Existing knowledge, knowledge creation capability, and the rate of new product introduction in high-technology firms. Academy of Management Journal, 48: 346-357

Smith, K.G., Grimm, C.M., Gannon, M.J. and Chen, M-J. 1991. Organizational information processing, competitive responses, and performance in the U.S. domestic airline industry, Academy of Management Journal, Vol. 34, No. 1, pp.60-85.

Steier, L. P., \& Miller, D. 2010. Pre-and post-succession governance philosophies in entrepreneurial family firms. Journal of Family Business Strategy, 1(3): 145-154.

Stewart, A. \& Hitt, M.A. 2012. Why can't a family business be more like a nonfamily business? Modes of professionalization in family firms. Family Business Review, 25(1): 58-86. 
Subramanian, M., \& Youndt, M. 2005. The influence of intellectual capital on the types of innovative capabilities. Academy of Management Journal, 48(3): 450-463.

Szulanski, G. 1996. Exploring internal stickiness: Impediments to the transfer of best practice within the firm. Strategic Management Journal, 17: 27-43.

Teece, D. J., Pisano, G., \& Shuen, A. 1997. Dynamic capabilities and strategic management. Strategic Management Journal, 18(7): 509-530.

Tihanyi, L., Johnson, R.A., Hoskisson, R.E., \& Hitt, M.A., 2003. Institutional ownership differences and international diversification: The effects of boards of directors and technological opportunity. Academy of Management Journal, 46(2): 195-211.

Wernerfelt, B. 1984. Consumers with differing reaction speeds, scale advantages and industry structure. European Economic Review, 24(2): 257-270.

Zahra, S. A. 2003. International expansion of U.S. manufacturing family businesses: The effect of ownership and involvement. Journal of Business Venturing, 18(4): 495-512.

Zahra, S. A., Neubaum, D. O., \& Larraneta, B. 2007. Knowledge sharing and technological capabilities: The moderating role of family involvement. Journal of Business Research, 60(10): 1070-1079.

Zander, U., \& Kogut, B. 1995. Knowledge and the speed of the transfer and imitation of organizational capabilities: An empirical test. Organization Science, 6(1): 76-92.

Zellweger, T. M., \& Astrachan, J. H. 2008. On the emotional value of owning a firm. Family Business Review, 21(4): 347-363. 
Table 1

Descriptive Statistics and Correlation Matrix

\begin{tabular}{|c|c|c|c|c|c|c|c|c|c|c|c|c|}
\hline & Mean & S.D. & 1 & 2 & 3 & 4 & 5 & 6 & 7 & 8 & 9 & 10 \\
\hline 1, Internationalization (ratio) & 0.35 & 2.27 & 1.00 & & & & & & & & & \\
\hline 2, Founding Generation Family Ownership \% & 2.31 & 9.68 & -0.01 & 1.00 & & & & & & & & \\
\hline 3, Later Generation Family Ownership \% & 5.60 & 16.36 & -0.01 & -0.04 & 1.00 & & & & & & & \\
\hline 5, Family Management (Family TMT member \#) & 0.31 & 0.65 & -0.03 & 0.32 & 0.45 & -0.12 & 1.00 & & & & & \\
\hline 6, TMT Size & 5.73 & 1.18 & 0.02 & -0.09 & -0.06 & 0.00 & -0.13 & 1.00 & & & & \\
\hline 7, CEO Duality & 1.02 & 1.12 & 0.03 & -0.04 & -0.04 & -0.09 & -0.07 & 0.14 & 1.00 & & & \\
\hline 8, Lone-Founder Ownership & 1.74 & 8.22 & 0.01 & -0.05 & -0.06 & 0.09 & -0.10 & -0.02 & -0.07 & 1.00 & & \\
\hline 10, Firm Size & 7.32 & 1.64 & 0.03 & -0.08 & -0.01 & -0.28 & -0.12 & 0.23 & 0.36 & -0.12 & -0.16 & 1.00 \\
\hline 11, Firm Age & 53.06 & 62.56 & 0.01 & -0.05 & -0.01 & -0.17 & -0.05 & 0.08 & 0.17 & -0.10 & -0.01 & 0.19 \\
\hline 12, Firm Risk & 8.12 & 10.91 & -0.02 & -0.02 & -0.04 & 0.11 & -0.04 & 0.00 & 0.02 & 0.10 & -0.03 & 0.07 \\
\hline 13, Previous Performance & 2.18 & 1.34 & -0.03 & -0.03 & -0.07 & 0.16 & -0.05 & -0.05 & -0.05 & 0.12 & 0.03 & -0.16 \\
\hline 14, Debt Ratio & 0.03 & 0.05 & 0.01 & -0.05 & 0.10 & -0.12 & 0.03 & 0.02 & 0.12 & -0.05 & 0.00 & 0.20 \\
\hline 15, Advertisement Ratio & 0.01 & 0.03 & 0.00 & 0.09 & 0.14 & -0.05 & 0.10 & 0.00 & -0.01 & 0.02 & 0.05 & 0.07 \\
\hline 16, Plant Newness & 0.50 & 0.14 & -0.05 & 0.01 & 0.08 & -0.23 & 0.12 & -0.01 & 0.04 & -0.05 & 0.04 & 0.10 \\
\hline 17, Inventory Ratio & 0.11 & 0.12 & 0.00 & 0.12 & -0.01 & -0.04 & 0.10 & -0.05 & -0.01 & -0.03 & 0.03 & -0.03 \\
\hline 19, Family Trust-Holdings & 0.34 & 0.47 & -0.04 & 0.32 & 0.36 & -0.07 & 0.58 & -0.14 & -0.16 & 0.16 & 0.12 & -0.16 \\
\hline 20, Family Sales Ratio by Industry & 0.17 & 0.29 & -0.04 & 0.19 & 0.27 & -0.19 & 0.46 & -0.09 & -0.07 & -0.06 & -0.02 & -0.05 \\
\hline \multirow[t]{2}{*}{ 21, Family Advertisement Ratio by Industry } & 0.17 & 0.33 & -0.03 & 0.16 & 0.27 & -0.19 & 0.38 & -0.05 & 0.00 & -0.04 & -0.03 & 0.03 \\
\hline & 11 & 12 & 13 & 14 & 15 & 16 & 17 & 18 & 19 & 20 & 21 & \\
\hline 11, Firm Age & 1.00 & & & & & & & & & & & \\
\hline 12, Firm Risk & -0.03 & 1.00 & & & & & & & & & & \\
\hline 13, Previous Performance & -0.08 & 0.19 & 1.00 & & & & & & & & & \\
\hline 14, Debt Ratio & 0.09 & -0.03 & -0.13 & 1.00 & & & & & & & & \\
\hline 15, Advertisement Ratio & -0.02 & 0.02 & 0.15 & 0.00 & 1.00 & & & & & & & \\
\hline 16, Plant newness & -0.01 & 0.10 & 0.00 & 0.07 & 0.05 & 1.00 & & & & & & \\
\hline 17, Inventory Ratio & 0.06 & 0.02 & -0.18 & 0.07 & -0.02 & 0.05 & 1.00 & & & & & \\
\hline 18, Previous International Sales & 0.00 & 0.01 & -0.02 & 0.01 & -0.01 & -0.03 & -0.01 & 1.00 & & & & \\
\hline 19, Family Trust-Holdings & -0.08 & 0.02 & 0.00 & -0.05 & 0.11 & 0.06 & 0.08 & -0.01 & 1.00 & & & \\
\hline 20, Family Sales Ratio by Industry & -0.04 & 0.03 & -0.05 & 0.02 & 0.18 & 0.16 & 0.13 & -0.03 & 0.35 & 1.00 & & \\
\hline 21, Family Advertisement Ratio by Industry & -0.02 & 0.03 & -0.04 & 0.03 & 0.18 & 0.12 & 0.14 & -0.03 & 0.29 & 0.68 & 1.00 & \\
\hline
\end{tabular}

All correlations above $|0.02|$ are significant at .10 or better for a two-tailed test 
Table 2

Fixed Effect Panel Regression on Internationalization

\begin{tabular}{|c|c|c|c|c|}
\hline & \multicolumn{2}{|c|}{ Model 1} & \multicolumn{2}{|c|}{ Model 2} \\
\hline Dependent Variables & \multicolumn{2}{|c|}{$\begin{array}{c}\text { Family Business } \\
\text { (Family Ownership }>=5 \%) \\
\text { Probit regression }\end{array}$} & \multicolumn{2}{|c|}{ International Sales } \\
\hline Variable & $\mathrm{B}$ & S.E. & $\mathrm{B}$ & S.E. \\
\hline Constant & $-1.626 * * * a$ & $(0.331)$ & -0.050 & $(1.317)$ \\
\hline Founding Generation Family Ownership & & & $-0.004 * *$ & $(0.002)$ \\
\hline Later Generation Family Ownership & & & $0.004 * *$ & $(0.002)$ \\
\hline Knowledge-based Resources & $-4.193 * * *$ & $(0.788)$ & 0.285 & $(0.866)$ \\
\hline Founding Generation Family Ownership $\times$ Knowledge-based Resources & & & $0.057^{*}$ & $(0.027)$ \\
\hline Later Generation Family Ownership $\times$ Knowledge-based Resources & & & $-0.114 *$ & $(0.046)$ \\
\hline Family Management & $1.762 * * *$ & $(0.101)$ & $0.064 \dagger$ & $(0.059)$ \\
\hline TMT Size & -0.050 & $(0.035)$ & $-0.023^{*}$ & $(0.022)$ \\
\hline CEO Duality & 0.041 & $(0.036)$ & 0.139 & $(0.102)$ \\
\hline Lone-Founder Ownership ${ }^{b}$ & & & $0.028 *$ & $(0.017)$ \\
\hline Non-Family Ownership & $-0.033 * * *$ & $(0.008)$ & $-0.0001 * *$ & $(0.002)$ \\
\hline Firm Size & -0.023 & $(0.029)$ & $-0.208 \dagger$ & $(0.051)$ \\
\hline Firm Age & $0.002 * * *$ & $(0.000)$ & $0.037 *$ & $(0.026)$ \\
\hline Firm Risk & $-0.011 * * *$ & $(0.003)$ & $-0.002 * * *$ & $(0.001)$ \\
\hline Previous Firm Performance & $-0.105^{* *}$ & $(0.035)$ & $-0.030^{*}$ & $(0.013)$ \\
\hline Debt Ratio & $1.146 \dagger$ & $(0.603)$ & -0.400 & $(0.635)$ \\
\hline Advertisement Ratio & -1.298 & $(1.432)$ & 1.698 & $(0.737)$ \\
\hline Plant newness & $-0.609 *$ & $(0.257)$ & -0.236 & $(0.448)$ \\
\hline Inventory Ratio & $0.695 \dagger$ & $(0.358)$ & -0.584 & $(0.165)$ \\
\hline Previous International Sales & -0.009 & $(0.010)$ & $-0.103 \dagger$ & $(0.074)$ \\
\hline Inverse Mill Ratio & & & $-0.006^{*}$ & $(0.020)$ \\
\hline Family Trust-Holdings & $2.307 * * *$ & $(0.102)$ & & \\
\hline Family Sales Ratio by Industry & $0.848 * * *$ & $(0.205)$ & & \\
\hline Family Advertisement Ratio by Industry & $0.233 * * *$ & $(0.057)$ & & \\
\hline Periods & \multicolumn{2}{|c|}{7} & \multicolumn{2}{|c|}{7} \\
\hline Cross-sections (Firms) & \multicolumn{2}{|c|}{758} & \multicolumn{2}{|c|}{758} \\
\hline Sample Size (Firm-Years) & \multicolumn{2}{|c|}{4,925} & \multicolumn{2}{|c|}{4,925} \\
\hline McFadden R Square & \multicolumn{2}{|c|}{0.76} & \\
\hline R Square & & & & \\
\hline F-statistic & & & & \\
\hline Absolute Log Likelihood & \multicolumn{2}{|c|}{684.90} & & \\
\hline
\end{tabular}

$\mathrm{a}, \dagger \mathrm{p}<.10 ; * \mathrm{p}<.05 ; * * \mathrm{p}<.01 ; * * * \mathrm{p}<.001$. Unstandardized coefficients are reported.

$\mathrm{b}$, The variable of Lone-Founder Ownership is not included in the Probit regression because family business and lone-founder firms are mutually exclusive. 


\section{Figure 1}

The Joint Effects of Founding and Later Generation Family Firms and R\&D Intensity on Internationalization

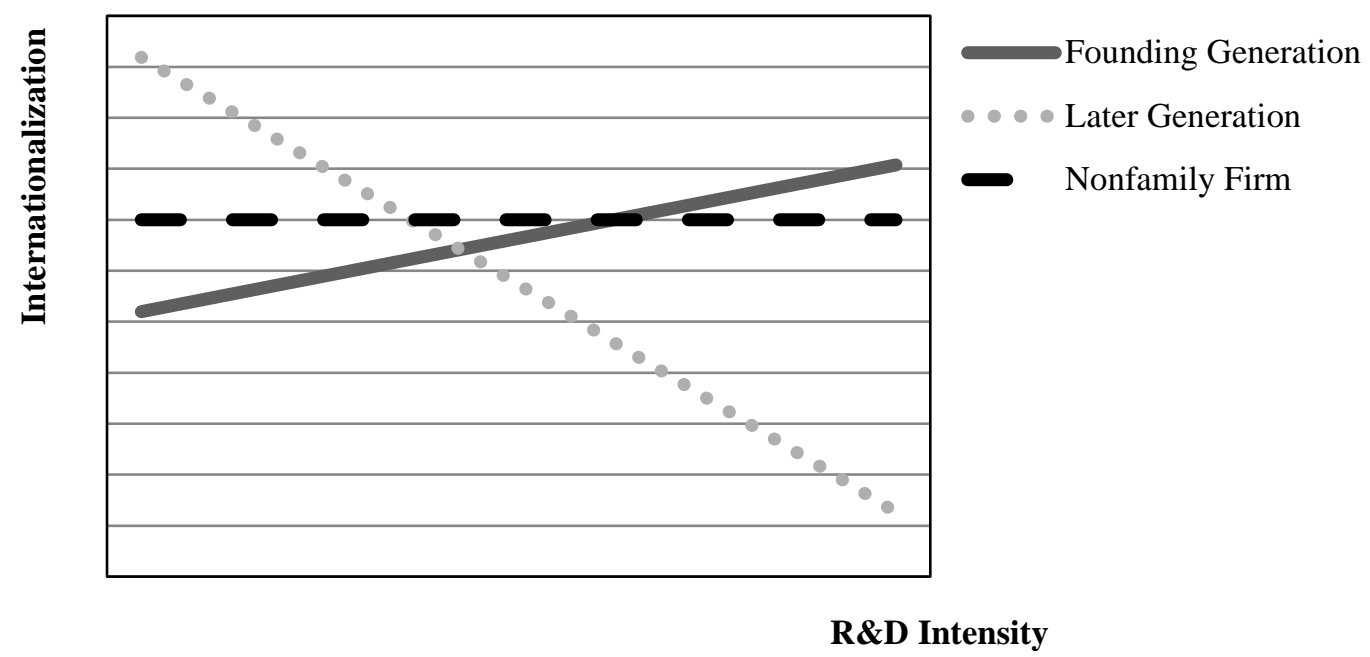

Notes:

a, Founding and later generation are plotted based upon means of founding and later generation family ownership

b, Insignificant estimated coefficient of knowledge-based resource is treated as 0 